\title{
MORELLI v. CEDEL: IGNORING JURISDICTIONAL LIMITS AND OUTFLANKING CONGRESS TOWARDS THE INTERNATIONALIZATION OF THE ADEA
}

\author{
Matthew H. Hawes ${ }^{*}$ and W. Scott Hardy ${ }^{* *}$
}

\section{INTRODUCTION}

Throughout the Twentieth Century, legislatures at all levels of American government have sought admirably to protect workers from a host of economic and societal ills by enacting broad-based remedial legislation. At times, these same legislatures have abdicated responsibility to the executive bureaucracy for further regulatory development. Without ensuring the attendant transfer of political accountability commensurate with the authority of the regulatory state, the delicate balance of powers crafted by the founders becomes skewed. Armed with the combined might of legislative fiat and unfettered enforcement power, the heavy hand of an over-zealous executive bureaucracy extends itself beyond the bounds initially established by the legislature in what is known as "mission creep." And, in the modern economy, the ramifications of mission creep are global.

Foreign businesses seeking to explore American markets through small American enterprises must remain wary of being caught in the morass of statutory and regulatory dictates that pervade American labor and employment legislation. As with their American counterparts, many of these small foreign businesses have neither the sophistication to understand the complexities of the American regulatory state nor the abundant resources necessary for compliance. Compounded by capricious statutory interpretations, their willingness to "invest in America" is diminished with the knowledge that they may be required to appease the regulatory community-and the Equal

\footnotetext{
* Matthew H. Hawes, Esq., is a tax department associate with the firm of Davis Polk \& Wardwell in New York, NY. He graduated summa cum laude in 2003 from the University of Pittsburgh School of Law. The opinions expressed herein are the authors' alone, and not the opinions of the firm or the firm's clients.

** W. Scott Hardy, Esq., is a Director (Partner) in the Labor and Employment and Employment Litigation Practice Groups with the firm Cohen \& Grigsby P.C. in Pittsburgh, PA. He graduated in 1996 from the Notre Dame Law School. The opinions expressed herein are the authors' alone, and not the opinions of the firm or the firm's clients.
} 
Employment Opportunity Commission (EEOC) in particular-when their equally small American counterparts are not required to do so. ${ }^{1}$ In such an anti-competitive environment, some foreign investors may conclude it is not worth the effort. ${ }^{2}$

Nearly forty years after the initial passage of the Age Discrimination in Employment Act of 1967 (ADEA), ${ }^{3}$ most of the world remains unsure as to the full scope of the statute's jurisdictional reach. Such uncertainty, when confronted by small foreign businesses seeking their fortunes in America, can manifest itself in the calculus of counting employees, i.e., whether non-United States citizens working for non-United States companies on non-United States soil are to be counted for purposes of determining whether the ADEA's coverage extends over an affiliated American entity employing a small complement of workers (less than twenty), on American soil. When such uncertainty exists, the simple matter of counting employees becomes a jurisdictional matter of international scope.

Political leaders of all ideologies regularly seek to attract foreign companies to invest in their communities, to employ their constituents, and to contribute to their tax bases. Yet these efforts are silently thwarted, in part, by significant, albeit incalculable, costs associated with the well-intentioned efforts of foreign (as well as domestic) businesses endeavoring to comply with the demands of the American regulatory state. The question ultimately becomes whether Congress intended to extend coverage of the ADEA to

1. It is certainly Congress's prerogative to enact legislation that protects employees working on American soil or otherwise favors American employers vis-à-vis foreign employers insofar as such legislation stays within the bounds of the U.S. Constitution, international law, and comity. The propriety or efficacy of such policies are far beyond the scope of this narrow exposition, and, accordingly, the authors offer no opinion in this regard.

2. Between 2001 and 2002 , new foreign investment dropped by more than half to just $\$ 52.6$ billion-a level not seen for nearly a decade and an $84 \%$ drop from a high of $\$ 335.6$ billion in 2000. News Release, Bureau of Economic Affairs, Foreign Direct Investors' Outlays to Acquire or Establish U.S. Businesses Fell Sharply in 2002 for the Second Year (June 2, 2003), available at http://www.bea.doc. gov/bea/newsrel/fdi02.htm (last visited Feb. 10, 2004) (illustrating that 2002 witnessed a precipitous decline in new foreign investment in the United States). These statistics are from the Bureau of Economic Analysis (BEA), U.S. Department of Commerce. The BEA studies the U.S. economy through statistical analyses with the goal of aiding policy makers in their decision-making processes. See Bureau of Economic Analysis, Mission Statement, available at http://www.bea.doc.gov/bea/about/mission.htm (last visited Jan. 17, 2004). The BEA does not expressly suggest that the U.S. regulatory state was the sole, or even a major factor in this decline. The BEA reports that the decline was due to "continuing weakness in the U.S. economy and in many foreign economies...." Id. Businesses and investors dislike any uncertainty or unpredictability caused by the U.S. regulatory state and consider those factors in their business's expansion or new investment decisions.

3. Age Discrimination in Employment Act of 1967, Pub. L. No. 90-202, 81 Stat. 602 (1967) (codified as amended at 29 U.S.C. $\S \S 621-634(2000)$ ). 
foreign entities or their foreign employees, and, by extension, whether Congress intended for the EEOC to extend its presence internationally.

The actual text of the ADEA and Congress's underlying intent is quite clear. Yet, at least one court-the United States Court of Appeals for the Second Circuit-has ignored both the text of the statute and the intent of Congress by overextending coverage of the ADEA internationally. Ironically, however, the court extended coverage of the ADEA in the name of Congress's purported intent. Indeed, the Second Circuit's ${ }^{4} 1998$ decision in Morelli $v$. Cedel $^{5}$ effectively rewrote Congress's definition of "employer" to extend coverage of the ADEA to small companies otherwise too small to implicate ADEA coverage but for the sizable foreign operations of a foreign parent entity. ${ }^{6}$

Although the Supreme Court has not had an opportunity to interpret the ADEA under circumstances in which the EEOC or a private litigant seeks to extend the ADEA's coverage to the small American subsidiary (i.e., an enterprise with fewer than twenty employees) of a foreign business employing a larger complement of overseas workers, at least one appellate court has had such an opportunity and other appellate courts soon will too. It is a matter of time before this issue percolates towards final disposition by the Supreme Court.

Enacted in 1967, the ADEA has the stated purpose of "promot[ing] employment of older persons based upon their ability rather than age ...."7 However, the ADEA does not regulate every business or protect every worker. Rather, Congress sought to regulate a narrower subset of companies and sought to limit the subset of protected individuals by extending coverage to the ADEA only to those individuals who are statutorily defined "employees," working for what the statute defines as "employers."

4. It is noteworthy, although in no way limiting the authority of the decision, that the opinion was authored by a visiting judge, Circuit Judge Cudahy of the Seventh Circuit, and joined by a senior judge, Senior Judge Newman. The panel consisted of only one full-time judge from the Second Circuit, Judge Calabresi.

5. Morelli v. Cedel, 141 F.3d 39, 44 (2d Cir. 1998).

6. See Angela Broughton et al., International Employment, 33 InT'L Law. 291, 314 (1999) (discussing Greenbaum v. Svenska Handelsbanken, 26 F. Supp. 2d 649 (S.D.N.Y. 1998), and the impact of Morelli v. Cedel on employment anti-discrimination law).

7. 29 U.S.C. $\S 621(b)$.

8. See Tomka v. Seiler Corp., 66 F.3d 1295, 1314 (2d Cir. 1995) (discussing the floor debate of the ADEA's older statutory cousin, Title VII of the Civil Rights Act of 1964 (Title VII), during which the minimum employee requirement was discussed as a provision to protect small businesses from the burdens of compliance and the costs of litigation associated with discrimination suits). 
The ADEA's jurisdictional constraints are accomplished through two limitations - one definitional and the other substantive. The statute defines an "employer" as a "person" engaged in an industry affecting commerce ${ }^{10}$ who has twenty or more employees for each working day in each of twenty ${ }^{11}$ or more calendar weeks in the current or preceding calendar year . . .",12 Further, while "employee" is defined quite broadly to include virtually all workers, ${ }^{13}$ the ADEA only protects those employees over forty years of age. ${ }^{14}$ Finally, and more substantive than definitional, the ADEA's reach is also limited by geography, citizenship, and the realities of corporate governance by excluding coverage "where the employer is a foreign person not controlled by an American employer." 15

Faced with deciding whether a small, seven-employee New York City "branch" office of a foreign business could meet the jurisdictional minimums required of the ADEA by counting the foreign business's foreign workers, the Morelli court made two important holdings: (i) that domestic operations of a foreign corporation not controlled by an American corporation would be subject to liability under the ADEA; and (ii) that foreign workers are to be counted towards reaching the statutory minimum when a domestic employer has fewer than twenty domestic employees. ${ }^{16}$ By reversing the district court and finding that "a foreign corporation's foreign employees are counted for the purpose of determining whether the corporation has enough employees to

9. The ADEA defines a "person" as "one or more individuals, partnerships, associations, labor organizations, corporations, business trusts, legal representatives, or any organized groups of persons." 29 U.S.C. $\S 630$ (a) (2000).

10. '“[I]ndustry affecting commerce' means any activity, business, or industry in commerce or in which a labor dispute would hinder or obstruct commerce or the free flow of commerce . ..." 29 U.S.C. $\S 630(\mathrm{~h})(2000)$.

11. The twenty employee minimum has fluctuated over the years. Beginning at fifty employees, it was finally set at its current level through an amendment in 1974. Fair Labor Standards Amendments of 1974, Pub. L. No. 93-259, § 28(a)(1), 88 Stat. 74 (1974) (codified as amended at 29 U.S.C. § 630(b) (2000)).

12. 29 U.S.C. $\$ 630(b)$.

13. "The term 'employee' means an individual employed by any employer .... [including] any individual who is a citizen of the United States employed by an employer in a workplace in a foreign country." 29 U.S.C. § 630(f) (narrow exception for state or political subdivision omitted).

14. 29 U.S.C. $\$ 631$ (a). As originally enacted, the ADEA protected only employees between the ages of forty and seventy years. However, a 1986 amendment struck the provision relating to the upper age limit. Age Discrimination in Employment Amendments of 1986, Pub. L. No. 99-592, §§ 2(c), 6(a), 100 Stat. 3342, 3344 (1986) (codified as amended at 29 U.S.C. § 631(c)(1)).

15. 29 U.S.C. $\$ 623(\mathrm{~h})(2)$ ("The prohibitions of this section shall not apply where the employer is a foreign person not controlled by an American employer.").

16. Morelli v. Cedel, 141 F.3d 39, 44-45 (2d Cir. 1998). 
be subject to the ADEA, ${ }^{17}$ the Second Circuit extended the dictates of the ADEA (and, consequently, the EEOC's investigative authority) upon foreign controlled businesses despite the text of the ADEA and Congress's contrary intent.

The focus of this exposition is the Second Circuit Court of Appeals' flawed reasoning in Morelli v. Cedel. But rather than merely present a case note, Morelli is intended to serve as a vehicle for a critique of the judiciary's penchant in the employment arena for supplanting its will for that of Congress and the consequent mission creep expected of the regulatory community. Joseph Story once stated, " "whatever may have been the private intentions of the framers ..., it is certain, that the true rule of interpretation is to ascertain the public and just intention from the language of the instrument itself, according to the common rules applied to all laws." "18

Part II of this Article discusses the legislative foundations of the ADEA, including its unremarkable history and known limitations, its narrow extraterritorial expansion, and the unintended birth of its internationality. In Part III, we discuss Morelliv. Cedel, its facts, how the district court correctly decided the matter, and how the Second Circuit veered off course. In Part IV, we provide the anatomy of how the Second Circuit outflanked Congress towards the internationality of the ADEA. We then conclude, in Part V, by identifying the negative geopolitical and economic consequences of judicial usurpation of congressional authority.

\section{Legislative Foundations of the ADEA}

\section{A. A False Start and a Humble Beginning}

The ADEA did not burst upon the employment scene in 1967 without warning or contemplation. Rather, the possibility of prohibiting age discrimination in employment surfaced in the debates over the passage of Title VII of the Civil Rights Act of 1964 (Title VII). The opponents of Title VII sought inclusion of an age provision in the broader bans on sex, race, and national origin discrimination that Congress eventually enacted. ${ }^{19}$ Mostly

17. Id. at 41 (emphasis added).

18. U.S. Department of Justice OfFice of Legal Policy: Report to the Attorney General: Using and Misusing Legislative History: A Re-Evaluation of the Status of Legislative History IN STATUTORY INTERPRETATION i (1989).

19. Daniel P. O’Meara, Protecting the Growing Number of Older Workers: The Age Discrimination in EMPloyment ACt 11 (1989). 
Southerners, the bill's opponents had hoped that Title VII would become "so broad and 'unreasonable' as to keep it from passing." 20

Seeking to forestall the opposition, Title VII's proponents asserted that not enough was known about the problems of age discrimination to effectively legislate a remedy, ${ }^{21}$ and succeeded in adding a provision directing the Secretary of Labor to engage in a study of the problems of workplace age discrimination. ${ }^{22}$

Delivered to Congress in 1965, the Secretary's report, entitled The Older American Worker: Age Discrimination in Employment, concluded that the problem of age discrimination was not prejudice but rather incorrect stereotypes in hiring. ${ }^{23}$ A particular focus was the practice of employers setting age limits beyond which candidates would no longer be considered for open positions. ${ }^{24}$ Such practices, the report found, led to long-term unemployment of older workers. ${ }^{25}$ The Secretary of Labor's recommendation: "A clear cut and implemented Federal policy ... [that] would provide a foundation for a much-needed vigorous, nationwide campaign to promote hiring without discrimination on the basis of age. ${ }^{, 26}$ Supporters of civil rights reform achieved a perfect victory. Not only had they won the passage of Title VII, but they also succeeded in making age discrimination in the workplace a matter of national concern.

In 1966, after another stunted attempt to place an age discrimination provision in other labor legislation, ${ }^{27}$ Congress ordered the Secretary of Labor to submit specific legislative recommendations to combat the ills identified in the report the previous year. ${ }^{28}$ Finally, three years after the first serious

20. Id. at 12 .

21. See id. at $12 \mathrm{n} .26$ and accompanying text.

22. Civil Rights Act of 1964, Pub. L. No. 88-352, § 715, 78 Stat. 241, 265 (1964).

23. O'Meara, supra note 19, at 13 (discussing the Secretary of Labor's report The Older AMERICAN Worker: Age Discrimination in EMPLOYMent).

24. Id.

25. Id. As O'Meara discusses, one study, upon which the report relied, "showed that approximately one-half of all job openings which developed in the private economy each year were closed to applicants over fifty-five ... and a quarter of these job openings were closed to applicants over forty-five." Id. (citing U.S. Dep't of Labor, The Older American Worker: Age Discrimination in Employment 1, 6 (1965), reprinted in EEOC,LEgisLATIVE History of THE Age DisCRimination IN EMPLOYMENT ACt 16, $23(1981))$.

26. H.R.ReP. No. 90-805 (1967), reprinted in 1967 U.S.C.C.A.N. 2213, 2214 (quoting U.S.DEP'T of LAbor, The Older American Worker: Age Discrimination in EMPloyment (1965)).

27. O'Meara, supra note 19, at 13-14. Provisions to prohibit age discrimination had actually gone so far as to be added to the Equal Pay Act of 1963, Pub. L. No. 88-38 (1963), before deletion while the bill was still in committee. $I d$.

28. See Fair Labor Standards Amendments of 1966, Pub. L. No. 89-601, § 606, 80 Stat. 845 (1966). 
attempt to address age discrimination in the American workplace, President Lyndon Johnson recommended passage of the ADEA in his "Older American" message delivered on January 23, 1967. ${ }^{29}$ The ADEA was finally enacted on December 15, 1967.

The ADEA is not, nor has it ever been, an overly long or complex statute. ${ }^{30}$ Slightly more than half the length of Title VII or the Americans with Disabilities Act (ADA),${ }^{31}$ the original 1967 version of the ADEA did not even receive much attention from the Congress that enacted it. ${ }^{32}$

Considering the bill's record and the original intention to use anti-age discrimination provisions as an impediment to the passage of Title VII, ${ }^{33}$ it is rather surprising that opposition to the ADEA was insignificant. ${ }^{34}$ No one in the Senate opposed the bill, ${ }^{35}$ and only eleven Congressmen in the House of Representatives stood in opposition-all because they believed its protections were not strong enough. ${ }^{36}$ The dearth of debate and wrangling led one commentator to quip: "The legislative history is exceedingly bland." 37 "Nobody seemed to pay much attention to what was actually in the law. Without much fanfare, the bill became law." ${ }^{38}$ Its quiet passage left one

29. H.R. ReP. No. 90-805 (1967), reprinted in 1967 U.S.C.C.A.N. 2213, 2214.

30. See O'MEARA, supra note 19 , at 3.

31. Although an imperfect comparis on, Title VII covers thirty-five pages of the United States Code. 42 U.S.C. $\S 2000 \mathrm{e}$ (2000). Likewise, the Americans with Disabilities Act spans thirty-two pages. 42 U.S.C. $\S \S 12101-12213$ (2000). This is contrast to the nineteen pages for the ADEA. 29 U.S.C. $\S \S 621-634(2000)$.

32. See O'MeAra, supra note 19, at 14.

33. See generally id. and accompanying text.

34. O'MEARA, supra note 19, at 14.

35. Lawrence M. Friedman, Your Time will Come: Law of Age Discrimination and MANDATORY RetiREMENT 15 (1984).

36. See Letter expressing Supplemental Views of Representatives Thompson of New Jersey, Holland, Dent, O'Hara of Michigan, Hawkins, Gibbons, Ford of Michigan, Hathaway, Mink, Scheuer, and Meeds on H.R. Rep. No. 805, 90th Cong. 1st Sess. 1967, reprinted in 1967 U.S.C.C.A.N. 2213, at 2225 (contending that the most flagrant form of discrimination, that which occurs in the airline industry with respect to stewardesses, is inadequately addressed by the statute because discrimination begins at an age far younger than the forty-five years provided in the law).

37. Friedman, supra note 35 , at 15 . The brevity of the legislative history brought another commentator to conclude that "[t]he legislative history of the ADEA is a model of lucidity." Alfred W. Blumrosen, Interpreting the ADEA: Intent or Impact, in EQuAL EMPLOYMENT ADVISORY COUNCIL, AGE Discrimination in Employment Act: A Compliance and Litigation Manual for Lawyers and Personnel Practitioners 68, 73 (Monte B. Lake ed., 1982). Brevity may make for a lucid legislative history, but it can make the interpretive task infinitely more difficult.

38. FRIEDMAN, supra note 35 , at 15. 
scholar to conclude that "Congress was totally unaware of the impact the ADEA would ultimately have." ${ }^{9}$

\section{B. The ADEA Knows Its Limits}

As is set forth in the Congressional Statement of Findings and Purpose, the ADEA is intended "to promote employment of older persons based on their ability rather than age; to prohibit arbitrary age discrimination in employment; to help employers and workers find ways of meeting problems arising from the impact of age on employment. ${ }^{, 40}$ Vague as these phrases are, the broad statement of legislative purpose might provide the best explanation of the scope of the law's intended prohibitions.

In enacting the ADEA, Congress expressed its will to prohibit certain companies from discriminating against certain individuals. ${ }^{41}$ Although described as "remedial and humanitarian," ${ }^{42}$ the ADEA was drafted with many significant limitations; not all "older" workers were protected and not all employing entities were covered "employers."

At the outset, the ADEA only protected workers between the ages of forty and sixty-five. ${ }^{43}$ Indeed, the ADEA had been described as protective not for the elderly, but for the middle-aged. ${ }^{44}$ Congress raised the upper age limit to

39. O'MeARA, supra note 19, at 14 (noting that "it was predicted that fewer than 1,000 charges would be filed annually").

40. 29 U.S.C. $\$ 621(b)(2000)$.

41. The ADEA makes it unlawful, inter alia, for an employer to "fail or refuse to hire or to discharge any individual or otherwise discriminate against any individual with respect to his compensation, terms, conditions, or privileges of employment, because of such individual's age." 29 U.S.C. § 623(a)(1). Congress further declared that the prohibitions of the ADEA shall be limited to individuals who are at least forty years of age. Id. $\S 631$ (a).

42. Moses v. Falstaff Brewing Corp., 525 F.2d 92, 93 (8th Cir. 1975).

43. Age Discrimination in Employment Act of 1967, Pub. L. No. 90-202 § 12, 81 Stat. 607 (1967) (codified as amended at 29 U.S.C. $\$$ 621-634 (2000)).

44. FRIEDMAN, supra note 35, at 13. The long-term effect of the ADEA has borne this out. One commentator has noted that "the problem at which Congress directed the ADEA, age discrimination in hiring and long-term unemployment among older workers, is no better and no worse than it was when the ADEA was passed in 1967." O’MEARA, supra note 19, at 2. Census data, compiled and published in support of a recent report by the AARP, a not-for-profit membership organization for people fifty years of age and older clearly strengthens this conclusion. See AARP, BEyond 50: A Report to the NAtion on ECONOMIC SECURITY (2001), available at http://www.research.aarp.org/econ/beyond_50_econ.html (last visited Jan. 17, 2004). In 1980, only $41 \%$ of the population over the age of fifty participated in the workforce. Twenty years later, in spite of all the advancements in healthcare, education, and antidiscrimination laws that number had increased to just 44\%. In fact, after 1980 the number of older workers participating in the labor force actually dropped as low as 38\%. It was not until 1996 that the numbers again surpassed the mark set in 1980. See AARP, Beyond 50: Summary Tables and Charts (2001), 
seventy in $1978,{ }^{45}$ and eventually removed the upper bound age limit completely for the majority of workers. ${ }^{46}$ Mandatory retirement, however, is still permissible for "bona fide executives or high policymakers" older than sixty-five, so long as certain pension requirements are met. ${ }^{47}$

Similarly, an ADEA covered "employer" was originally limited to "a person $^{48}$ engaged in an industry affecting commerce ${ }^{49}$ who has twenty-five or more employees for each working day in each of twenty or more calendar weeks in the current or preceding calendar year ...." ${ }^{50}$ The term "employee" was merely defined, albeit circularly, as "an individual employed by any employer." ${ }^{51}$ By adopting these limiting definitions of the terms "employer" and "employee," Congress had not only sought to cloak the ADEA in the constitutionality of the Commerce Clause, but had also sought to insulate smaller domestic businesses from the expense ${ }^{52}$ and inconvenience of compliance..$^{53}$

available at http://www.research.aarp.org/econ/beyond_50_econ_tables.html (follow link for 'Employment') (last visited Jan. 17, 2004).

45. Age Discrimination in Employment Act Amendments of 1978, Pub. L. No. 95-256, § 12(a), 92 Stat. 189 (1978).

46. Age Discrimination in Employment Amendments of 1986, Pub. L. No. $99-592$ § 2(c)(1), 100 Stat. 3342 (1986).

47. 29 U.S.C. $\$ 631(\mathrm{c})(2000)$ (requiring an aggregate pension of at least $\$ 44,000$ per year in benefits for mandatory retirement to be permissible). The ADEA also provides for an exemption situation where "age is a bona fide occupational qualification reasonably necessary to the normal operation of the particular business." Id. §623(f)(1). Examples of bona fide occupational qualifications (BFOQs) include a mandatory retirement age for airline flight engineers, Iervolino v. Delta Air Lines, Inc., 796 F.2d 1408, 1421 (11 th Cir. 1986), cert. denied, 479 U.S. 1090 (1987), and maximum ages for new hires to work within a correctional facility, Stewart v. Smith, 673 F.2d 485, 500 (D.C. Cir. 1982).

48. Section 11(a) of the original text of the ADEA defined the term "person" to mean "one or more individuals, partnerships, associations, labor organizations, corporations, business trusts, legal representatives, or any organized groups of persons." Age Discrimination in Employment Act of 1967, Pub. L. No. 90-202 § 11(a), 81 Stat. 602, reprinted in 1967 U.S.C.C.A.N. 658, 662 (codified as amended at 29 U.S.C. $\S 631$ (a) (2000)).

49. Section 11(h) of the ADEA defined the term "industry affecting commerce" to mean "any activity, business, or industry in commerce or in which a labor dispute would hinder or obstruct commerce or the free flow of commerce and includes any activity or industry 'affecting commerce' within the meaning of the Labor-Management Reporting and Disclosure Act of 1959." Id. § 11(h), reprinted in 1967 U.S.C.C.A.N. 658, 663-64 (codified as amended at 29 U.S.C. $\$ 630(\mathrm{~h})(2000)$ ).

50. Id. § 11(b), reprinted in 1967 U.S.C.C.A.N. 658, 662 (codified as amended at 29 U.S.C. $\S 630(\mathrm{~b})(2000))$.

51. Id. §11(f), reprinted in 1967 U.S.C.C.A.N. 658, 663 (codified as amended at 29 U.S.C. § 630(f) (2000))

52. See, e.g., Tomka v. Seiler Corp., 66 F.3d 1295, 1314 (2d Cir. 1995) (discussing the floor debate of Title VII and suggesting that the minimum employee requirement was intended to protect small businesses from the burdens of compliance and the costs of litigation associated with discrimination suits).

53. We do not intend to suggest that small business should feel free to discriminate in a manner 


\section{A Narrow Expansion of Extraterritorially Leads to the Unintended Birth of Internationality}

Between 1967 and 1984, the world's economies seemingly began to meld. U.S. companies began to explore opportunities overseas, and foreign enterprises began to invest in and merge with U.S. companies on American soil. The economic realities of a global marketplace outpaced the initial provincial intentions of the ADEA. Before too long, appellate court decisions in cases such as Cleary v. United States Lines, Inc. ${ }^{54}$ and Thomas v. Brown and Root, Inc. ${ }^{55}$ found the proscriptions of the ADEA did not extend to the extraterritorial operations of U.S. businesses. ${ }^{56}$ Indeed, although courts had faithfully applied the text of the ADEA, based upon clear statutory language limiting the statute's reach to the domestic real $m,{ }^{57}$ such disciplined refusal to expand the ADEA without clear legislative authorization did not go unnoticed.

Congress responded swiftly by holding hearings on the issue. Senator Charles E. Grassley, Chairman of the Subcommittee on Aging, Committee on Labor and Human Resources, presided over the hearings on "age discrimination and overseas Americans" on September 23, 1983. ${ }^{58}$ The hearings with the Senator began by expressly referencing the court opinions in Cleary v. United States Lines, Inc. ${ }^{59}$ and Zahourek v. Arthur Young \& Co. ${ }^{60}$ and indicating that the purpose of the hearing was to investigate whether "further clarification of congressional intent would be helpful in insuring the protection of thousands of American workers." ${ }^{\prime 1}$

prescribed by the ADEA from a moral or ethical standpoint. Smaller employers may indeed have a legal obligation to comply with state statutes and local ordinances very similar to the ADEA. Rather, we simply mean that certain smaller business are not subject to the ADEA.

54. 728 F.2d 607 (3d Cir. 1984).

55. 745 F.2d 279 (4th Cir. 1984).

56. Id. at 281; Cleary, 728 F.2d at 610.

57. See Cleary v. United States Lines, Inc., 728 F.2d 607, 610 (3d Cir. 1984) (holding that the ADEA does not apply to "Americans employed outside the United States by American employers"); Thomas v. Brown \& Root, Inc., 745 F.2d 279, 281 (4th Cir. 1984) (same); Zahourek v. Arthur Young \& Co., 750 F.2d 827, 828-29 (10th Cir. 1984) (same).

58. Age Discrimination and Overseas Americans, 1983: Hearing Before the Subcomm. on Aging of the Senate Comm. on Labor and Human Res., 98th Cong. 1 (1983) [hereinafter Hearings: Age Discrimination and Overseas Americans].

59. 728 F.2d 607 (3d Cir. 1984).

60. 750 F.2d 827 (10th Cir. 1984).

61. Hearings: Age Discrimination and Overseas Americans, supra note 58, at 2. 
Clarence Thomas, then the Chairman of the EEOC, testified that the ADEA, as then written, "[did] not apply to [Americans working for American companies abroad] for basically the same reasons set out by the court in Cleary .... Neither the ADEA nor its legislative history give any indication that the statute should apply to acts outside this country's borders." ${ }^{\prime 62}$ Thomas further testified:

It can be argued that the ADEA should be amended to provide extraterritorial coverage to Americans working in foreign countries for American companies. This is underscored by [T]itle VII's extraterritorial application and the long-recognized fact that the purposes and goals of the two statutes are parallel, that is, to eliminate discrimination in employment. The only way to make the two laws consistent and insure that other individuals do not find themselves in Mr. Cleary's situation in the future is to enact legislation such as that proposed by Chairman Grassley to close the existing loophole. ${ }^{63}$

Congress subsequently amended the ADEA in 1984 to extend its coverage to U.S. citizens employed in foreign countries by U.S. entities or their subsidiaries. ${ }^{64}$ This amendment modified the definition of "employee" to include "any individual who is a citizen of the United States employed by an employer in a workplace in a foreign country." ${ }^{65}$ It also added an entire subsection under the section entitled "Prohibition of age discrimination." ${ }^{66}$ This added subsection states:

(h) Practices of foreign corporations controlled by American employers; foreign employers not controlled by American employers; factors determining control (1) If an employer controls a corporation whose place of incorporation is in a foreign country, any practice by such corporation prohibited under this section shall be presumed to be such practice by such employer.

(2) The prohibitions of this section shall not apply where the employer is a foreign person not controlled by an American employer.

(3) For the purpose of this subsection the determination of whether an employer controls a corporation shall be based upon the-

62. Id. at 3 .

63. Id.

64. See S. ReP. No. 98-467, at 2 (1984), reprinted in 1984 U.S.C.C.A.N. 2974, 2975. The 1984 amendments also added a new defense to ADEA liability in the context of employing aU.S. citizen overseas where compliance with the ADEA would cause the employing entity to violate the laws of the host nation. See Older Americans Act Amendments of 1984, Pub. L. No. 98-459, § 802(b)(1), 98 Stat. 1767, 1792 (1984) (codified at 29 U.S.C. § 623(f)(1) (2000)). Additionally, the 1984 amendments increased from $\$ 27,000$ to $\$ 44,000$ the annual private retirement benefit level necessary for a bona fide executive or high policymaking position to be exempt from ADEA coverage. See id. § 802(c)(1), 98 Stat. 1767, 1792 (codified at 29 U.S.C. $\S 631(\mathrm{c})(1)$ ).

65. Older Americans Act Amendments of 1984, $\S 802$ (a) (amending section 11(f) of the ADEA) (codified at 29 U.S.C. $\$ 630(f)(2000)$ ).

66. 29 U.S.C. $§ 623$. 

(A) interrelation of operations,
(B) common management,
(C) centralized control of labor relations, and
(D) common ownership or financial control, of the employer and the corporation. ${ }^{67}$

Congress believed that these amendments were "carefully worded to apply only to citizens of the United States who are working for U.S. corporations or their subsidiaries[, and that it would] not apply to foreign nationals working for such corporations in a foreign workplace and it [would] not apply to foreign companies which are not controlled by U.S. firms." Accordingly, determining whether an employing entity (i.e., a "person" as defined by 29 U.S.C. $§ 630(a)$ ) is an "employer" covered by the ADEA is simple enough when the entity at issue is a domestic enterprise that employs twenty or more employees in the United States. ${ }^{69}$ The 1984 amendments ensure that the same determination is made when the employing entity has fewer than twenty employees working in the United States but also employs a larger complement of U.S. citizens on foreign soil either directly or through a subsidiary. ${ }^{70}$ By virtue of the 1984 amendments, the ADEA clearly applies to these U.S. citizens working for U.S. employers or their subsidiaries on foreign soil. ${ }^{71}$

The result is not so clear, however, when attempting to determine whether the ADEA covers an employing entity that has fewer than twenty employees working in the United States but that is owned or otherwise controlled by a foreign entity that employs a larger complement of foreign individuals working on foreign soil. The text of the ADEA does not expressly and unambiguously declare whether such employing entities are subject to the ADEA under this narrow circumstance. The colloquy between Senator Grassley and Clarence Thomas at the Senate Subcommittee's hearing on these amendments $^{72}$ is prophetic of the dilemma at hand:

Senator Grassley: I would like to ask you, though, if you have had an opportunity to review the bill that we have drafted, whether or not you feel it is (2000)).

68. S. ReP. No. 98-467, at 27-28 (1984), reprinted in 1984 U.S.C.C.A.N. 2974, 3000-3011.

69. 29 U.S.C. $\$ 630(a)$, (b), and (f).

70. Older Americans Act Amendments of 1984, $\S 802$ (a) (amending section 11(f) of the ADEA) (codified at 29 U.S.C. $\$ 630(f)(2000)$ ).

71. $I d$.

72. Hearings: Age Discrimination and Overseas Americans, supra note 58, at 4-5. 
sufficient to close the loophole I suggest exists, and whether or not you have some additional suggestions in regard to it.

Clarence Thomas: Yes, Mr. Chairman, I have had an opportunity to look at it. It is rather brief. Although the [EEOC] has not taken a position on whether or not there should be legislation in this area, if you have legislation, it should definitely be specific as to which employers are covered.

For example, right now it is not clear from your draft bill whether or not the term "employee" also includes employees of foreign corporations. We think that any legislation would have to definitely be specific and indicate under what circumstances we are to become involved in the area of discriminatory termination of older employees.

Senator Grassley: Is the inference that our bill is not specific enough?

Clarence Thomas: That is right.

Senator Grassley: I appreciate that. ${ }^{73}$

Despite Thomas's advice to Senator Grassley, Congress never clarified the bill.

Twenty years have since passed, and during that time the interconnectedness of the global marketplace has increased exponentially with the end of the Cold War and the advent of technologies such as the Internet. In 1991, at least 2,000 U.S. companies operated 21,000 overseas offices in 121 countries. $^{74}$ By 1998, an estimated 300,000 Americans worked abroad. ${ }^{75}$ More importantly, for purposes of the interstice in ADEA coverage being explored here, foreign firms began looking to operate or otherwise invest in businesses on American soil. ${ }^{76}$ Local political leaders in the nation's rust belt frequently travel to other countries in efforts to attract foreign investments to "create" jobs and increase the local tax base. ${ }^{77}$ Accordingly, an increasingly global economy continues to put the text of the ADEA, and, indeed, congressional will, to the test.

73. Id.

74. Michael Starr, Who's the Boss? The Globalization of U.S. Employment Law, 51 Bus. Law. 635, 636 (1996) (citing 137 Cong. Rec. H3934 (daily ed. June 5, 1991)).

75. Arylyn Tobias Gajilan \& Jennifer Tanaka, Cyberscope: Globetrotters' Friend, NewsweEk, June 22,1998 , at 8 .

76. Foreign companies have purchased American companies such as Columbia Pictures, Zenith, Firestone, and Southland/7-Eleven. See After Japan: South Korea's Firms Are on a Buying Binge Overseas. Will They Repeat the Mistakes or the Successes of the Japanese?, Economist, Oct. 5, 1996, at $17,18$.

77. See, e.g., Joyce Gannon, Plans for Luring Foreign Firms Aired, Pittsburgh Post-Gazette, Oct. 11, 2002, at C15 (reporting on local leaders' trade and investment summit where discussions included results of trade missions to Germany and the United Kingdom by Pittsburgh officials). 
Some commentators suggest that the American economy was largely selfcontained when Congress enacted the ADEA in 1967-that is, foreign companies rarely operated in the United States and American companies rarely operated abroad. ${ }^{78}$ Assuming this is true, it is no wonder that the text of the ADEA did not expressly address whether international workers were to be counted with U.S. workers for purposes of determining coverage. Subsequent amendments to the ADEA have done some to clarify this murky issue, yet, as the Second Circuit's decision in Morelli v. Cedel makes evident, definitive resolution remains either elusive or flawed.

\section{Internationalization of the ADEA in MorelLI V. CEDEL}

Before Morelli, all federal courts that addressed the issue uniformly held that only domestic employees of a foreign employer were to be counted for purposes of satisfying the ADEA and Title VII statutory minimums. ${ }^{79}$ Even within the Second Circuit, the weight of authority "held that the foreign employees of a foreign corporation [did] not count towards the statutory minimum required under the ADEA and Title VII. Instead, the relevant group is the number of employees in the United States." ${ }^{\circ 0}$ In one opinion, the District Court for the Southern District of New York explained: "Only those employees ... who work in the United States for twenty or more calendar weeks per year are to be counted for purposes of determining whether the enterprise is covered by the provisions of the ADA, ADEA[,] and Title VII." 81

District courts within the Second Circuit acknowledged there were "no Title VII or ADEA case[s] where a court considered foreign employees outside the United States to find that the employer met the statutory minimum.." ${ }^{82}$ In Rao v. Kenya Airways, Ltd., ${ }^{83}$ a judge in the Southern District

78. Pietro S. Nivola, Having It All? Domestic Regulations and the Global Economy, BrookingS REV., Winter 1996, at 16, 18.

79. Minutillo v. Aqua Signal Corp., No. 96-3529C, 1997 WL 156495, at *2 (N.D. Ill. Mar. 31, 1997) (discussing Title VII and the ADEA); Kim v. Dial Serv. Int'l, Inc., No. Civ. 96-3327 (DLC), 1997 WL 5902, at *3 (S.D.N.Y. Jan. 8, 1997) (discussing the ADEA and Title VII); Robins v. Max Mara, U.S.A., Inc., 914 F. Supp. 1006, 1009 (S.D.N.Y. 1996) (discussing the ADA, ADEA, and Title VII); Rao v. Kenya Airways, Ltd., No. 94 Civ. 6103 (CSH), 1995 WL 366305, at *2 (S.D.N.Y. June 20, 1996) (discussing Title VII); Goyette v. DCA Adver., Inc., 830 F. Supp. 737, 745 (S.D.N.Y. 1993).

80. Kim, 1997 WL 5902, at *3.

81. Robins, 914 F. Supp. at 1009 .

82. Morelli v. Cedel, No. Civ. 96-2874 (MBM), 1997 WL 61499, at *2 (S.D.N.Y.). The court notes that the ADEA and Title VII use identical definitions of employer with the exception of the ADEA requiring a statutory minimum of twenty employees while Title VII requires only fifteen. Id. at $* 2 \mathrm{n}$. 2 .

83. No. 94 Civ. 6103 (CSH), 1995 WL 366305 (S.D.N.Y. June 20, 1996). 
of New York specifically rejected the counting of foreign workers to reach the statutory minimum under Title VII. ${ }^{84}$ The Rao court determined that while the definition of employee does not specify that only those workers found within the United States are counted under the statute, Title VII does specifically reject its application " "with respect to the foreign operations of an employer that is a foreign person not controlled by an American Employer." ${ }^{85}$ In extending limited extraterritorial application of the ADEA, these courts relied upon the foreign employer exemption expressly set forth in the ADEA, which states: "The prohibitions of [the ADEA] shall not apply where the employer is a foreign person not controlled by an American Employer." ${ }^{" 86}$ If the foreign operations of a foreign corporation is not considered an employer, the "foreign employees of a foreign corporation are not considered employees . . ." ${ }^{87}$

\section{A. An Unremarkable Case}

Bland facts rarely garner much attention for a case and the facts of Morelli are as straightforward and unexceptional as they come. In a time when discrimination cases can make headlines for either magnitude or salaciousness, this case has neither. On its facts, the case is simply a basic workplace discrimination charge. Maybe it should be little shock that from a case warranting so little notice comes an opinion with such implications. ${ }^{88}$

Ida Morelli was employed in the New York branch office of defendant Cedel Bank, S.A. ${ }^{89}$ Cedel, an international securities trading company, ${ }^{90}$ maintained its principal place of business and the majority of its employees in Luxembourg. ${ }^{91}$ In addition to its main office, the firm operated satellite

84. Id. at $* 2$.

85. Id. at *2 (quoting 42 U.S.C. $\$ 2000 \mathrm{e}-1$ (c)(2) (2000)).

86. 29 U.S.C. $\$ 623(\mathrm{~h})(2)(2000)$; see also 42 U.S.C. § 2000e-1(c)(2) (stating Title VII does "not apply with respect to the foreign operations of an employer that is a foreign person not controlled by an American employer").

87. Rao, 1995 WL 366305, at *2; accord Minutillo v. Aqua Signal Corp. No. 96-3529, 1997 WL 156495 , at *1 (N.D. Ill. Mar. 31, 1997) (“[F]oreign employees of [defendant] may not be counted for Title VII [or ADEA] purposes.”).

88. Appellant's Joint Appendix at 107A, Morelli v. Cedel, 141 F.3d 39 (2d Cir. 1998) (No. 97-7277) [hereinafter Joint Appendix].

89. Morelli v. Cedel, 141 F.3d 39, 41 (2d Cir. 1998).

90. Joint Appendix, supra note 88, at 113A.

91. Appellee's Brief at 2, Morelli v. Cedel, 141 F.3d 39 (2d Cir. 1998) (No. 97-7277). 
offices in London, Tokyo and Hong Kong, ${ }^{92}$ as well as a mere eleven employee office in New York. ${ }^{93}$

Hired in 1984, Morelli worked as an administrative assistant from the time Cedel opened its New York branch office until being discharged in 1994. ${ }^{94}$ Her discharge came less than one year after the instillation of a new head of the New York office. ${ }^{95}$ Following Morelli's departure, Cedel had no employees over the age of forty in New York. ${ }^{96}$ Morelli was fifty-five at the time. ${ }^{97}$

Shortly after her termination, Morelli filed a complaint with the New York State Division of Human Rights (NYDHR) alleging violations of the New York Human Rights Act (NYHRA) ${ }^{98}$ the ADEA, and the Employment Retirement Income Security Act (ERISA). ${ }^{99}$ After its investigation, the NYDHR found no probable cause to believe Cedel had engaged in discriminatory action and issued a determination order dismissing the complaint. ${ }^{100}$ Having complied with the administrative prerequisites, Morelli exercised her right to file suit in federal court and brought suit under the NYHRA, ADEA, and ERISA. ${ }^{101}$

Cedel moved for dismissal of the ADEA claim on the basis of lack of subject matter jurisdiction, contending that it employed only eleven workers in its New York office. ${ }^{102}$ Cedel argued that it did not meet the ADEA's

92. $I d$.

93. Id.; see also Affidavit of Percy P. Lopez, in Joint Appendix, supra note 87, at 71A.

94. Morelli, 141 F.3d at 41; see also Appellee's Brief at 3, Morelli (No. 97-7277).

95. Morelli, 141 F.3d at 41; see also Appellee's Brief at 3, Morelli (No. 97-7277).

96. Appellee's Brief at 3, Morelli (No. 97-7277).

97. See Morelli, 141 F.3d at 40. The record includes specific actions taken by the defendant upon termination. Those actions are not germane to the scope of this article.

98. N.Y. EXEC. LAW § 296 (Consol. 2003).

99. Morelli v. Cedel, No. Civ. 96-2874, 1997 WL 61499, *1 (S.D.N.Y. Feb. 13, 1997). The ERISA claim is not a subject of this note.

100. DHR Determination and Order, in Joint Appendix, supra note 88, at 67A-68A.

101. Amended Compliance at 96 Civ. 2874, in id. at 42A-50A.

102. Morelli, 1997 WL 61499 , at $* 2$. 
definition of employer, ${ }^{103}$ that the ADEA did not apply to it, and, therefore, that the complaint must be dismissed. ${ }^{104}$

Morelli agreed that Cedel did not employ the required twenty employees within the United States, but insisted that jurisdiction was still appropriate ${ }^{105}$ because Cedel employed hundreds of workers world-wide. ${ }^{106}$ These employees, the plaintiff argued, should be counted in reaching the statutory minimum. ${ }^{107}$ On this most basic issue formed the question: How does one count to twenty under the ADEA?

\section{B. Getting It Right: The Southern District of New York}

To support her position before the United States District Court for the Southern District of New York, Morelli cited Goyette v. DCA Advertising Inc. ${ }^{108}$ In Goyette, the same district court had found that Dentsu, Inc., Defendant DCA's foreign corporate parent based in Japan, could be held liable for its subsidiary's Title VII violations even though the parent did not employ the statutory minimum of fifteen employees required by Title VII. ${ }^{109}$ The Goyette court reasoned that although Denstu did not have any domestic employees under a common law interpretation of the word, "that fact [was] irrelevant given the nature of Dentsu's control over DCA's firing policies," 110

103. Id. Circuits are split on the question of whether the employee statutory minimum is a jurisdictional prerequisite appropriate for a FED. R. CIV. P. 12(b)(1) dismissal or a question of fact appropriate for summary judgment. See, e.g., Rogers v. Sugar Tree Prods., Inc., 7 F.3d 577, 579 (7th Cir. 1993) (holding for federal subject matter jurisdiction to exist under ADEA, defendant must meet Act's definition of "employer," i.e., defendant must employ twenty or more individuals); EEOC v. St. Francis Xavier Parochial Sch., 117 F.3d 621, 623-24 (D.C. Cir. 1997). While the Second Circuit has not joined the Seventh Circuit in holding that the requirement is jurisdictional, within the Second Circuit such a distinction appears to have little relevance. See Dresher v. Shatkin, 280 F.3d 201, 202 n.2 (2d Cir. 2002) (affirming district court dismissal for lack of jurisdiction where employer did not have fifteen employees as required by Title VII. The court noted that although Second Circuit precedent did not treat the matter as jurisdictional "no practical difference results from that difference in theory and terminology."). E.g., Da Silva v. Kinsho Int'l Corp., 229 F.3d 358 (2d Cir. 2000).

104. See Morelli, 1997 WL 61499, at *2.

105. $I d$. 97-7277)

106. See id.; see also Appellant's Brief at 3, Morelli v. Cedel, 141 F.3d 39 (2d Cir. 1998) (No.

107. $I d$.

108. Goyette v. DCA Adver., Inc., 830 F. Supp. 737 (S.D.N.Y. 1993).

109. Id. at 745; see also Morelli v. Cedel, No. Civ. 96-2874, 1997 WL 61499, at *2 (S.D.N.Y. Feb. $13,1997)$. The term "employer" is defined under Title VII, $\$ 2000$ e(b) as "a person engaged in an industry affecting commerce who has fifteen or more employees for each working day in each of twenty or more calendar weeks in the current or preceding calendar year ...." 42 U.S.C. $\$ 2000 \mathrm{e}(\mathrm{b})$ (2000).

110. Goyette, 830 F. Supp. at 745. 
and Dentsu's discriminatory policy, "which affected more than fifteen employees in the United States." "111

The Morelli district court acknowledged that although similarities between Title VII and the ADEA $^{112}$ sometimes permit analogizing the interpretations of one statute to aid the interpretations of the other, Goyette was not on point. ${ }^{113}$ The key distinction, the district court noted, was that the Goyette court did not count the foreign employees, ${ }^{114}$ as Morelli requested here. ${ }^{115}$ The court further pointed out that the "plaintiff cites no Title VII or ADEA case where a court considered foreign employees outside the United States to find that the employer met the statutory minimum." 116

The Morelli district court ultimately held that it is entirely inappropriate to count foreign workers employed overseas-not only are they not "employees" protected under the statute, but also the ADEA does not apply to foreign operations of foreign companies. ${ }^{117}$ The court reasoned that while the last sentence of the definition of employee in $\S 630$ (f) does extend the definition to include some workers overseas, it is expressly limited to "citizen[s] of the United States." 118

To substantiate its determination, the district court pointed out that prior to 1984, the ADEA did not protect American citizens employed overseas even when working for a U.S. company. ${ }^{19}$ "[C]ourts which have considered the question have uniformly held that the ADEA . . . [did] not apply extraterritorially." ${ }^{20}$ It was only through an amendment to the ADEA

111. Id. ("Accordingly, because Dentsu's policy affected more than fifteen employees in the United States, we find that Dentsu employed fifteen employees within the meaning of Title VII.") (emphasis added).

112. "The language of Title VII, 42 U.S.C. $\$ 2000 \mathrm{e}(\mathrm{b})$ is identical to the language in the ADEA, 29 U.S.C. $\S 630$ (b), with the only difference that the ADEA applies to employers with twenty or more employees, and Title VII applies to employers with fifteen or more employees." Morelli, 1997 WL 61499, at $* 2$ n. 2 .

113. Id. at $* 2$.

114. $I d$.

115. Goyette, unlike Morelli, turned on a piercing the corporate veil approach holding that the parent corporation was liable due to the excessive control over DCA's employment policies. See Goyette v. DCA Adver., Inc., 830 F. Supp 737, 744-45 (S.D.N.Y. 1993).

116. Morelli v. Cedel, No. Civ. 96-2874, 1997 WL 61499, at *2 (S.D.N.Y. Feb. 13, 1997) (citing Kim v. Dial Serv. Int'1, Inc., No. Civ. 96-3327, 1997 WL 5902, at *3 (S.D.N.Y. Jan. 8, 1997) (discussing the ADEA and Title VII); Robins v. Max Mara, U.S.A., 914 F. Supp. 1006 (S.D.N.Y. 1996) (discussing the ADA, ADEA, and Title VII); Rao v. Kenya Airways, Ltd., No. Civ. 94-6103, 1995 WL 366305, at *2 (S.D.N.Y. June 20, 1996) (discussing Title VII)).

117. Morelli, 1997 WL 61499, at*3.

118. Id. (citing 29 U.S.C. § 630(f) (2000)).

119. Id.

120. Wolf v. J.I. Case Co., 617 F. Supp. 858, 866 (E.D. Wis. 1985). 
designed to close a "loophole" that enabled American companies to transfer workers to subsidiaries overseas and then discriminate against them on the basis of age ${ }^{121}$ that the statute was extended to protect U.S. citizens employed by a U.S. company or a foreign company controlled by a domestic entity. ${ }^{122}$

The Morelli court reasoned that because the 1984 amendments established that the ADEA does not apply to the foreign operations of a foreign company, the foreign employees of those companies should not be counted for jurisdictional purposes. ${ }^{123}$ The court pointed to the new language of $\S 623(\mathrm{~h})$ :

(1) If an employer controls a corporation whose place of incorporation is in a foreign country, any practice by such corporation prohibited under this section shall be presumed to be such practice by such employer.

(2) The prohibitions of this section shall not apply where the employer is a foreign person not controlled by an American employer. ${ }^{124}$

As the Morelli district court explained, even the Supreme Court recognized that the very purpose of the 1984 amendment, which added the last sentence of the definition of employer, "was 'to mak[e] provisions of the [ADEA] apply to citizens of the United States employed in foreign countries by U.S. corporations or their subsidiaries." "125 The Morelli court echoed the Supreme Court's conclusion:

If [the definition of employee] did not include United States citizens employed abroad until the 1984 amendment, and the 1984 amendment applied only to United States citizens employed abroad, then, in the absence of any indication to the contrary in the amendment, § 630(f) [the definition of employee] does not include foreign citizens

121. As stated by the then EEOC Chairman Clarence Thomas in Senate hearings concerning the purpose of the 1984 amendment, "[t]he only way to ... insure that other individuals do not find themselves in Mr. Cleary's situation . . . is to enact legislation . . . to close the existing loophole." Hearings: Age Discrimination and Overseas Americans, supra note 58, at 3; see also supra note 58 and accompanying text. Chairman Thomas was referring to the plaintiff in Cleary v. United States Lines, Inc., 728 F.2d 607 (3d Cir. 1984). Cleary had been employed by a foreign subsidiary of the defendant at the time of his termination and, as a result of the extraterritorial limitations of the ADEA before its 1984 amendment, he was not protected by the Act. $I d$. at 610 .

122. Ralis v. RFE/RL, Inc., 770 F.2d 1121, 1124 (D.C. Cir. 1985) (rejecting the application of the ADEA to plaintiff's 1981 claim because "[t]he crystal clear language of the ADEA as it stood in 1981 admits of no reasonable reading other than that given to it by the federal district court and the Third Circuit in Cleary and by our own District Court in the case at hand"); Hearings: Age Discrimination and Overseas Americans, supra note 58, at 3; see also Cleary, 728 F.2d at 607.

123. Morelli v. Cedel, No. Civ. 96-2874, 1997 WL 61499, at *4 (S.D.N.Y. Feb. 13, 1997).

124. Id.; 29 U.S.C. $§ 623(\mathrm{~h})(1)-(2)(2000)$.

125. Morelli, 1997 WL 61499, at*3 (quoting EEOC v. Arabian Am. Oil Co., 499 U.S. 244, 259 (1991) (internal citation omitted)). 
employed abroad. Indeed, in the 1984 amendments Congress . . could have included foreign employees employed abroad. [But] [b]ecause foreign employees employed abroad are not "employees" within the ADEA's definition of "employee," § 630(f), they should not be counted as "employees" under $\S 630(\mathrm{~b})$ to determine whether an employer has the minimum number of employees. ${ }^{126}$

When considered with the amendment to $\S 623(\mathrm{~h})$, the 1984 amendments to $\S 630(f)$, which expand the definition of employee to include those U.S. citizens working abroad, "establish that the ADEA applies only to United States citizens working abroad for United States companies or their foreign subsidiaries, and not to United States citizens employed by foreign companies." "27 The district court reasoned that "[i]t makes no sense to count as employees under $\S 630$ (b) foreign employees, who are not protected by the ADEA, of foreign companies, which are not subject to the ADEA."128

"Thus," the court summarized as it dismissed Ida Morelli's ADEA claim, "foreign employees employed outside the United States are not counted as employees to meet the statutory minimum under $\S 630(\mathrm{~b})$ both because they are not "employees" protected by the statute and because the prohibitions of the ADEA do not apply to a foreign company's foreign operations." 129 But such a clear, consistent analysis was not destined to last long as the Second Circuit Court of Appeals reviewed the lower court's decision.

\section{The Second Circuit Veers Off-Course}

Like the district court before it, the Second Circuit began its analysis with an acknowledgment of the undisputed fact that Cedel was "a foreign employer with fewer than 20 employees in its sole U.S. branch."130 However, the similarities to the lower court's analysis ended as quickly as they began.

The court next turned to the portion of the ADEA that Congress added in 1984. As discussed in part IIIA, Congress added § 2(h)(2) in direct response to the courts' decisions that "the ADEA did not apply to "Americans employed outside the United States by American employers." "131 Through this amendment, the statute now provides " $[t]$ he prohibitions of this section shall

126. Id.

127. Id. at $* 4$.

128. Id.

129. $I d$.

130. Morelli v. Cedel, 141 F.3d 39, 41 (2d Cir. 1998).

131. Id. at 42 (citing Cleary v. United States Van Lines, Inc., 728 F.2d 607, 610 (3d Cir. 1984)). 
not apply where the employer is a foreign person not controlled by an American employer." 132

The Second Circuit recognized and dismissed the idea that this new subsection "might suggest that the ADEA ... does not apply to the domestic operations of foreign employers." "133 Instead, the court explained the "plain language . . . is not necessarily decisive if it is inconsistent with Congress' clearly expressed legislative purpose, ${ }^{\prime 134}$ and that the context of the 1984 amendment "reveals that Congress' purpose was not to exempt the domestic workplaces of foreign employers from the ADEA's prohibition[s]." ${ }^{135}$ Rather, the court reasoned, the purpose of this provision "was to limit the reach of an extraterritorial amendment adopted as part of the same legislation." 136

The extraterritorial amendment referenced by the Second Circuit contained three parts. The first part modified the definition of employe $e^{137}$ to include "any individual who is a citizen of the United States employed by an employer in a workplace in a foreign country." 138 In other words, the extraterritorial amendment provided ADEA coverage to Americans working overseas for companies meeting the ADEA definition of employer. This definitional amendment was, the court noted, coupled with an expansion of the statute to impute liability on a U.S. parent corporation for the discriminatory actions of a foreign subsidiary corporation it controls. This second part of the amendment provided that "[i]f an employer controls a corporation whose place of incorporation is in a foreign country, any practice by such corporation prohibited under this section shall be presumed to be such practice by such employer." "139 Finally, as the Second Circuit points out, in addition to expanding the scope of the statute in the first two parts to the 1984 extraterritorial amendment, Congress also limited the impact of the amendments through a "foreign law exception." "140 This third part was merely

132. 29 U.S.C. $\$ 623(\mathrm{~h})(2)(2000)$. The subsection was originally codified at $\S 623(\mathrm{~g})$, but there was already a subsection $(\mathrm{g})$. The mistake was corrected in a 1986 amendment.

133. Morelli, 141 F.3d at 42.

134. $I d$.

135. $I d$.

136. $I d$.

137. Id. Section 11(f) of the ADEA is codified at 29 U.S.C. $\S 630(\mathrm{~b})(2002)$.

138. 29 U.S.C. $\S 630(f)(2000)$.

139. Id. $\S 623(\mathrm{~h})(1)$.

140. The exception, codified at 29 U.S.C. $\$ 623(\mathrm{f})(1)$, insulates employers from liability for "practices involv[ing] an employee in a workplace in a foreign country" where compliance with the ADEA "would cause [the] employer, or a corporation controlled by such employer, to violate the laws of the country in which such workplace is located." 29 U.S.C. § 623(f)(1) (2000). See Mahoney v. RFE/RL, Inc., 47 F.3d 447 (D.C. Cir. 1995) (holding that due to § 623(f)(1), defendant, Radio Free Europe, need not comply with 
intended to "conform the ADEA's reach to 'the well-established principle of sovereignty, that no nation has the right to impose its labor standards on another country." "'141 Analyzing these three parts together, the Second Circuit rationalized that " $[t]$ here is no evidence in the legislative history that these amendments were intended to restrict the application of the ADEA with respect to domestic operations of foreign employers." 142

The Second Circuit further opined that the ADEA's statutory cousins, namely Title VII and the ADA, expressly limit their exclusions to the "foreign operations of an employer that is a foreign person not controlled by an American employer." ${ }^{43}$ As there is no legislative history for these provisions ${ }^{144}$ evidencing Congress's intention to create any such difference in scope between the ADEA and Title VII or the ADA, "[i]t is not apparent why the domestic operations of foreign companies should be subject to Title VII and the ADA, but not to the ADEA."145 Such an exemption, the Second Circuit concluded, would undercut the very purpose of the ADEA to promote the employment of older persons. ${ }^{146}$

Leaving aside the fact that these provisions presume the foreign company is already an "employer" for jurisdictional purposes, in other words, the court concluded that because the plain language of the ADEA's sister statutes only excluded the overseas operations of non-U.S. controlled foreign businesses, the ADEA, which does not contain any similar language, should be read to provide identical coverage.

The Second Circuit next turned to the question of whether overseas employees can be counted in determining whether a foreign employer is subject to the ADEA through the counting of overseas workers. ${ }^{147}$ After concluding that, as originally drafted, the broad language in the definition of "employee" does not apply to restrict the scope of coverage but merely

the ADEA and maintain employment for its American employees in Munich where compliance with the ADEA would cause the violation of a lawful collective bargaining agreement mandating retirement when employees reach the age of sixty-five).

141. Morelli v. Cedel, 141 F.3d 39, 43 (2d Cir. 1998) (quoting S. ReP. No. 98-467, at 27 (1984), reprinted in 1984 U.S.C.C.A.N. 2974, 3000).

142. $I d$.

143. Id. (citing 42 U.S.C. $\S \S 2000 \mathrm{e}-1(\mathrm{c})(2), 12112(\mathrm{c})(2)(\mathrm{b})(2000))$.

144. Both the ADA and Title VII were amended as part of the Civil Rights Act of 1991. See Civil Rights Act of 1991, Pub. L. No. 102-166, § 109(a), 105 Stat. 1077 (1991).

145. Morelli, 141 F.3d at 43.

146. $I d$.

147. Id. at 44 . 
provides a numerical minimum, the court analyzed the ADEA following the 1984 amendments. ${ }^{148}$

In the Second Circuit's view, the 1984 amendment supplements the definition of employee to include U.S. citizens employed overseas by an employer. ${ }^{149}$ The court reasoned that " $[\mathrm{t}]$ his revision . . . does not establish that the employees, wherever located, of a foreign corporation with a U.S. branch are not 'employees' under the ADEA" because the statute does not make a distinction between domestic and foreign employers. ${ }^{150}$ Further, the court reasons, the $\S 623(\mathrm{~h})(2)$ exclusion of ADEA protections for an individual working overseas for an employer that is foreign and not controlled by an American employer does not provide support for only counting domestic employees; § 623(h)(2) was only intended to limit liability with respect to those foreign workers. ${ }^{151}$ Consequently, "if Congress had wished to restrict the definition of 'employee' to exclude a foreign employer' s foreign workers, it certainly could have done so directly when it amended [the definition of employee] in 1984." ${ }^{152}$ In essence, while Congress was amending the ADEA to provide protections for Americans working overseas, Congress could also have limited the definition of employee to specifically exclude a foreign employer's workers. But because Congress did not, the court rationalized, the 1984 extraterritorial amendments supplement the definition of employer rather than restrict it.

The court concluded that merely because the overseas employees of a foreign employer are not protected by the ADEA does not mean that they should not be counted. ${ }^{153}$ After all, the court reasoned, the ADEA counts employees under age forty even though they do not receive the protections of the statute. ${ }^{154}$ So because neither the original ADEA nor the 1984 extraterritorial amendments exclude the counting of foreign workers employed overseas, the counting of those foreign workers must be permitted, making Cedel an employer under the ADEA even though it employed only eleven in its U.S. operations.

148. $I d$.

149. $I d$.

150. Id.

151. Id.

152. Id.

153. Id.

154. Id. at 44-45. 


\section{Anatomy of the Second Circuit's Flanking Maneuver}

How did the Second Circuit find statutory authorization permitting a broad interpretation of the coverage of the ADEA when every court that had addressed similar issues merely found limitations? A careful reading of the Second Circuit's opinion in Morelli demonstrates the court's unwillingness to be faithful to congressional intent despite a stated intention to do so. Students of the various theories of statutory construction will recognize that the Second Circuit claims to be ascribing to an intentionalist approach, yet it employs a hodge-podge of approaches-mostly dynamic - to arrive at its desired result. A result, in this instance, through which the Second Circuit clearly supplants its will for that of Congress.

While most readers will be familiar with the basic canons of statutory interpretation, a brief review of some of the major precepts is appropriate. The purpose of this Article remains, however, not to propose a theory of statutory interpretation or even to explore the many theories that exist. Rather, we explicate the flaws in the Second Circuit's reasoning under the model it claims to use in reaching its decision in Morelli. In analyzing the court's rationale we do not decide what an employee is under the ADEA. In other words, we do not seek to determine, in the oft-used jurisprudential example, what constitutes a vehicle when applying a park ordinance prohibiting the use of vehicles ${ }^{155}$ but, rather, demonstrate that the statute-the ADEA-was not even intended to apply to this park, i.e., foreign workers employed by foreign businesses.

\section{A. Three Interpretive Theories: An Analytical Framework for Statutory Interpretation}

A statute generally is considered to be "the written will of the legislature expressed according to the form necessary to constitute it a law of the state, and rendered authentic by certain prescribed forms and solemnities." ${ }^{156}$

155. As an introduction to, or as a vehicle for, statutory interpretation and jurisprudential theories, professors and scholars alike often utilize a hypothetical where it is asked if a city's park ordinance banning the use of vehicles in the park includes the use of bicycles, horses, or just motor-driven conveyances. Of course, even with the narrowest interpretation of vehicle, the Socratic method tends to lead even the wariest student to eventually ban electric wheelchairs and remote-controlled cars. See generally H.L.A. Hart, Positivism and the Separation of Law and Morals, 71 HARV. L. Rev. 593, 607 (1958).

156. Earl T. Crawford, The Construction of Statutes 1 (Gaunt, Inc. 1999) (1940). 
Article I, Section 7, Clause 2 of the United States Constitution, known as the bicameralism and presentment clause, provides the forms and solemnities necessary for the Congress to impose its will by enacting such statutes. ${ }^{157}$

The statutory will of Congress is neither self-enforcing nor selfinterpreting-our Constitutional Republic is comprised of three equal branches of government expected to impose checks and balances on one another. The judicial branch is to interpret congressional will, ${ }^{158}$ and the executive branch is to enforce congressional will as interpreted by the judiciary.

The evolution of the modern regulatory bureaucracy complicates the delicate balance of power conceived by the founders and accentuates the critical importance of statutory interpretation and application. ${ }^{159}$ To maintain the regulatory state, Congress enacts statutes with ever increasing frequency. As this abundance of statutory law has grown, the law has become more detailed in its prescriptions. ${ }^{160}$ Too often, Congress directs its will, not to the citizenry, but an executive bureaucracy, ${ }^{161}$ which by design was intended to apply the law, not create it.

Indeed, "the legitimacy and operation" of congressional will sometimes rest with the department, agency, bureau, commission, or official whose job it is to enforce the statute. ${ }^{162}$ These executive branch delegates, or regulatory communities, have been given considerable deference in their interpretations of the statutes they are charged with enforcing. ${ }^{163}$ Yet oftentimes they are

157. "Every Bill which shall have passed the House of Representatives and the Senate, shall, before it becomes a Law, be presented to the President of the United States; If he approve he shall sign it ...." U.S. Const. art. I, § 7, cl. 2; see also INS v. Chadha, 462 U.S. 919, 944-45 (1983).

158. Marbury v. Madison, 5 U.S. 137, 177 (1803) ("It is emphatically the province and duty of the judicial department to say what the law is. Those who apply the rule to particular cases, must of necessity expound and interpret that rule.").

159. For a general discussion on this topic, see William N. Eskridge, JR., Dynamic Statutory INTERPRETATION 2 (1994).

160. One commentator has opined that " $[\mathrm{b}] \mathrm{y}$ degrees, ... our extensive level of social ambition leads us to a very complex set of legal rules, ... which only lawyers can understand and navigate, and then at very stiff fees." Richard A. Epstein, Simple Rules For a Complex World xi (1995).

161. Just such an example is found within the tax code which empowers the Secretary of the Treasury Department to "prescribe all needful rules and regulations for the enforcement of the [Code]" I.R.C. $\S 7805$ (a) (2003).

162. ESKRIDGE, JR., supra note 159 , at 2.

163. See Chevron U.S.A., Inc. v. Natural Res. Def. Council, Inc., 467 U.S. 837 (1984) (holding, in part, that executive branch regulations should be granted substantial deference when not contrary to the statutory scheme). In reviewing the Environmental Protection Agency's (EPA) interpretation of the Clear Air Act, the U.S. Supreme Court held that, as a threshold matter, courts must give effect to the unambiguously expressed intent of Congress, but that if a statute does not unambiguously express Congress's intent then such courts must give deference to an agency's permissible construction of the 
unaccountable to the citizenry and operate unchecked, executing personal or institutional interpretations of a given statute upon members of the public without the resources or stamina to resist.

Accordingly, the judiciary must increase its vigilance in conducting statutory interpretations ${ }^{164}$ to prevent further erosion of congressional will by the executive branch. Of course the judiciary must also be disciplined so as not to supplant its own will for that of the legislature. As Alexander Hamilton admonished in Federalist No. 78, "[t] he courts must declare the sense of the law; and if they should be disposed to exercise WILL instead of JUDGMENT, the consequence would equally be the substitution of their pleasure to that of the legislative body." 165

Academics and jurists who ascribe to the school of "dynamic statutory construction" refuse to heed Hamilton's admonishment. This crowd eschews "original intent" and "plain meaning" approaches to statutory construction, and describes the underlying precepts of such intentionalist approaches as a "dubious description of practical reality, and a dreary aspiration for our polity." "166

Dynamic theories of statutory interpretation adhere to the belief that one cannot interpret the meaning of a statute as not fixed until it is applied to concrete circumstances and that the meaning is neither uncommon nor illegitimate for the meaning of a provision to change over time ${ }^{167}$ By contrast, the intentionalist approaches emphasize legislative intent as the goal of statutory interpretation. Accordingly, the executive and judicial branches, as well as the citizenry, should apply legislative directives in a manner consistent

statute that it enforces. Id. at 844 .

164. For a brief discussion of the U.S. Supreme Court's involvement in statutory construction vis-àvis constitutional interpretation, see ESKRIDGE, JR., supra note 159, at 2.

165. The Feder Alist No. 78, at 103 (Alexander Hamilton) (Tudor Publ'g Co. 1937). Ironically, the meaning of this passage, beyond the plain words of the text, is subject to some debate. Eskridge, Frickey, and Garrett suggest that Hamilton's "warning was sounded in connection with [his] discussion of judicial review and not of statutory interpretation." William N. EsKRIDGE, JR. ET AL., Legislative AND Statutory Interpretation 232 n.37 (2000) [hereinafter Eskridge, Jr., Interpretation]. Yet these commentators appear to ignore the directly preceding sentences of Federalist No. 78, which state: "It can be of no weight to say that the courts, on the pretense of a repugnancy, may substitute their own pleasure to the constitutional intention s of the legislature. This might as well happen in the case of two contradictory statutes; or it might as well happen in every adjudication upon any single statute." FEDERALIST No. 78, supra, at 103 .

166. ESKRIDGE, JR., supra note 159 , at 9.

167. Id. 
with the legislature's expectations and intent when enacting a particular statute. ${ }^{168}$

The third grouping of interpretative theories, known as textualist theories, seek to apply the "plain meaning" of statutory text either as the best evidence of legislative intent or as the only authoritative basis for interpretation. One version of textualism, known as the "new textualism," has been ascribed to by Justice Scalia in several of his judicial opinions and in the Tanner Lectures at Princeton University. ${ }^{169}$ The new textualism "holds that the only object of statutory interpretation is to determine the meaning of the text and that the only legitimate sources for this inquiry are text-based or text-linked sources." ${ }^{170}$ According to Justice Scalia, this method is most consistent with the rule of law and the separation of judicial and legislative powers. ${ }^{171}$

Courts often times use an amalgamation of interpretive theories. For its part, the United States Supreme Court almost invariably purports to begin any interpretive process with the statutory text. ${ }^{172}$ The Justices have employed varying interpretive analyses, however, ranging from text-oriented approaches to approaches willing to subsume the statutory text, and, at times, to ignore it in furtherance of a results-oriented approach. ${ }^{173}$ Sometimes the statutory text is the beginning and the end of the interpretive process; at other times it is merely the beginning of the process; and still at other times, the text is simply not part of the process.

In Morelli, the Second Circuit ignored the statutory text of the ADEA and employed a dynamic interpretive methodology-under the intellectually dishonest guise of an intentionalist approach-to conclude that the congressional purpose of protecting older employees from discrimination

168. ESKRIDGE, JR., InTERPRETATION, supra note 165, at 214 n.7.

169. See Lecture by Antonin Scalia, Common-Law Courts in a Civil-Law System: The Role of U.S. Federal Courts in Interpreting the Constitution and Laws (Mar. 8-9, 1995), available at http://www.tannerlectures.utah.edu/lectures/scalia97.pdf (last visited Jan. 17, 2004), in ANTONIN SCALIA, A Matter of Interpretation: Feder al Courts and the LaW (Amy Gutman ed., 1997); see also Bank One Chicago v. Midwest Bank \& Trust Co., 516 U.S. 264, 279 (1996) (Scalia, J., concurring, in part); Chisom v. Toemer, 501 U.S. 380, 404 (1991) (Scalia, J., dissenting); Green v. Bock Laundry Mach. Co., 490 U.S. 504, 527 (1989) (Scalia, J., concurring in the judgment). See generally William Eskridge, Jr., The New Textualism, 37 UCLA L. Rev. 621 (1990).

170. ESKRIDGE, JR., INTERPRETATION, supra note 165, at 228.

171. Id. at 229 .

172. Christian E. Mammen, Using Legislative History in American Statutory INTERPRETATION 10 n.6 (2002).

173. For example, in Holder v. Hall, 512 U.S. 874, 882-83 (1994), Justice Kennedy ignores the text of the Voting Rights Act of 1965, in a challenge to a rural Georgia county's single-member county commission as volatile of the Fourteenth and Fifteenth Amendments, and instead relies on legislative history as controlling the rule of decision. 
would be furthered if the will of Congress, as expressed clearly in the text of the statute, were ignored.

\section{B. The Second Circuit's Strained Reasoning}

The Second Circuit's plain language analysis as applied in Morelli is flawed. "A fundamental canon of statutory construction is that, unless otherwise defined, words will be interpreted as taking their ordinary, contemporary, common meaning." ${ }^{174}$ Consequently, the 1984 amendments, particularly $\S 4(\mathrm{~h})(2)$ - which specifies that the "prohibitions of this section shall not apply where the employer is a foreign person not controlled by an American employer" ${ }^{\prime 175}$ — should be given its plain language meaning; all foreign firms are exempt from the ADEA unless controlled by an American corporation. Even the Second Circuit in Morelli acknowledges that "[a]n absolutely literal reading of $\S 4(\mathrm{~h})(2)$ might suggest that the ADEA also does not apply to the domestic operations of foreign employers." 176 In stating so, the Second Circuit implicitly admits that the text of the ADEA is clear enough, yet reaches for the legislative history not to clarify, but to obfuscate. ${ }^{177}$

The Second Circuit chose to ignore the express will of Congress and offered the excuse that statutory language is "not necessarily decisive if it is inconsistent with Congress' clearly expressed legislative purpose." ${ }^{\prime 18}$ The Second Circuit contends that the purpose of $\S 4(\mathrm{~h})(2)$ was not to create an exemption for foreign employers within the United States, but to limit the reach of the concurrent extraterritorial expansion. There is some case law to support this position. ${ }^{179}$

174. Perin v. United States, 444 U.S. 37, 42 (1979).

175. 29 U.S.C. $\$ 623(\mathrm{~h})(2)(2002)$.

176. Morelli v. Cedel, 141 F.3d 39, 42 (2d Cir. 1998).

177. See Mammen, supra note 172, at 31-32 ("In general, before the Court will cite legislative history, it must have determined that the statutory text, interpreted on its own, meets a threshold level of uncertainty. Typically, this uncertainty takes the form of ambiguity or absurdity.").

178. Morelli, 141 F.2d at 42.

179. See Goyette v. DCA Adver., Inc., 830 F. Supp. 737, 745 (S.D.N.Y 1993); EEOC v. Kloster Cruise Ltd., 888 F. Supp 147, 149-51 (S.D. Fla. 1991) (rejecting defendant claims to the contrary and holding that $\S 4(\mathrm{~h})(2)$ does not provide for the wholesale exclusion of foreign companies from ADEA compliance); Helm v. S. African Airways, No. Civ. 84-5404 (MJL), 1987 WL 13195, at *7 (S.D.N.Y. June 25, 1987) ("We find nothing in the ADEA or its legislative history to indicate that the 1984 amendments were intended to exclude American citizens working within the United States from coverage."). 
However, the so-called "clearly expressed legislative purpose" propounded by the Second Circuit does not support a conclusion that Congress intended the ADEA to require the counting of foreign workers employed overseas by foreign-controlled businesses. The House Report concerning the 1984 amendment clearly proclaims that "the amendment is carefully worded to apply only to citizens of the United States who are working for U.S. corporations or their subsidiaries." ${ }^{180}$ Yet the Second Circuit relies on this "carefully worded" text to reach the negative inference that because Congress did not choose to exclude a foreign employer's foreign workers, it is appropriate to count them to reach the statutory minimum. ${ }^{181} \mathrm{By}$ that rational, the ADEA mandated the counting of foreign workers even before the statute was amended, a conclusion in conflict with the decisions of every court that had addressed the matter before the Second Circuit did so in Morelli. ${ }^{182}$

One circuit court has determined that when analyzing a remedial statute such as the ADEA, "[a] procedural requirement of the Act, of doubtful meaning in a given case, should not be interpreted to deny an employee a claim for relief unless to do so would clearly further some substantial goal of the Act." 183 The statutory minimum, however, which is designed to protect small employers, is far from a mere procedural requirement. The floor debate over the ADEA's analogous statute, Title VII, as described in Tomka v. Seiler Corp. ${ }^{184}$ indicates that the costs associated with defending against discrimination claims was a factor in the decision to implement a minimum employee requirement. ${ }^{185}$ Of course, this rationale further suggests that Congress might not have intended the Act to govern foreign employers operating small domestic offices.

The Second Circuit's holding, taken to its logical conclusion, could easily result in the ADEA's application to a foreign company with just one U.S. employee and nineteen world-wide employees. Certainly, such a situation

180. H.R. ReP. No. 98-1037, at 28 (1984).

181. See Morelli, 141 F.3d at 44.

182. "Accordingly, in determining whether Cedel satisfies the ADEA's 20-employee threshold, employees cannot be ignored merely because they work overseas." Morelli v. Cedel, 141 F.3d 39, 45 (2d Cir. 1998). "We do not follow the district courts that have concluded — without apparent exception-that only the domestic employees of a foreign employer are counted ...." Id. at 45 n.1.

183. Moses v. Falstaff Brewing Corp., 525 F.2d 92, 94 (8th Cir. 1975) (citations omitted).

184. Tonika v. Seiler Corp., 66 F.3d 1295, 1314 (2d Cir. 1995).

185. Id. (citing 110 Cong. ReC. S. 13,092 (1964) (statement of Sen. Cotton); 110 Cong. ReC. S. 13,088 (1964) (statement of Sen. Humphrey); 110 Cong. REC. S. 13,092-93 (1964) (statement of Sen. Morse)). 
would create precisely the burden Congress had intended to avoid by establishing a twenty employee jurisdictional minimum.

\section{Equal Standards or Unequal Burdens?}

In addition to protecting small businesses from the "costs" of compliance, "Congress based its twenty-employee minimum on "the practical consideration that a larger employer with more varied jobs could more constructively utilize an older worker's skills." "186 When a foreign employer has fewer than twenty employees working within the United States, there is no variety of jobs in which the employer can utilize the employee's skills. In the example of the not unlikely outgrowth of the Second Circuit's Morelli holding raised above, where there exists only one worker employed domestically, in order to "utilize" the employee's skills the employer will be forced to transfer the individual overseas. This is problematic. Skills, language, abilities, and the like do not necessarily translate to cross-border employment, yet liability remains.

Furthermore, enforcement of the ADEA against the foreign firm with a very small domestic office is likely to result in greater harm to the domestic employee than if the ADEA did not provide protections at all. Foreign employers will know that their overseas operations are expressly excluded from coverage under the Act. As a result, the foreign employer can transfer its domestic employees to an overseas office merely for the pretext of termination or other discriminatory practice. The American citizen who could have been let go within the United States and possibly sought a remedy through state anti-discrimination laws which usually have significantly lower statutory minimums will be discriminated upon, terminated, and stranded in a foreign country without remedy.

The 1984 amendment closed the loophole in the ADEA that enabled domestic firms to engage in this practice. Matters of international comity will, however, always restrict Congress from closing the loophole enabling foreign employers to engage in this shell-game. Congress certainly could not have intended to provide an end-run around compliance with the ADEA, but the Morelli court's holding does just that and in a manner bound to realize even greater harm to the very citizens the statute was intended to protect.

186. Palmer v. Ark. Council on Econ. Educ., 154 F.3d 892, 897 (8th Cir. 1998) (quoting Kelly v. Wauconda Park Dist., 801 F.2d 269, 272 n.3 (7th Cir. 1986), cert. denied, 480 U.S. 940 (1987)). 


\section{The Role of the EEOC}

In Morelli, the Second Circuit Court of Appeals noted that the EEOC guidelines were persuasive in their determination that the ADEA applies to the domestic operations of foreign firms. ${ }^{187}$ "It is well-established that the interpretation of a statute by the agency charged with its enforcement is entitled to great deference." 188 As noted by the Second Circuit in Yerdon $v$. Henry, ${ }^{189}$ however, the EEOC does not necessarily have deferential authority to issue rules or regulations. ${ }^{190}$ "Thus, the weight accorded a particular EEOC guideline or interpretation ... depends upon the 'thoroughness evident in its consideration, the validity of its reasoning, its consistency with earlier and later pronouncements, and all those factors which give it power to persuade, if lacking power to control.","191

Courts have not always been persuaded by the guidelines promulgated by the EEOC. In Cleary v. United States Lines, Inc. ${ }^{192}$ the Third Circuit Court of Appeals rejected the plaintiff's argument that the court should defer to the EEOC's interpretation of the ADEA merely under the general rule of deferring to the interpretation of the agency charged with enforcement of a statute. ${ }^{193}$ Instead, the Third Circuit determined that the question of whether or not the ADEA applied extraterritorially "is a matter of pure statutory construction, and agency expertise is not controlling." ${ }^{194}$ Nevertheless, even giving due regard to the EEOC's guidelines, the Commission's interpretation lacks significant support earning little, if any, weight.

In determining that the ADEA governs the actions of a foreign firm operating in the United States, the EEOC merely asserts that the employer is "subject to the Act" because "a foreign employer enjoys the benefits and

187. See Morelli v. Cedel, 141 F.3d 39, 44 (2d Cir. 1998).

188. Wolf v. J.I. Case Co., 617 F. Supp. 858, 866 (E.D. Wis. 1985) (citing Youakim v. Miller, 425 U.S. 231, 235 (1976)); Chevron U.S.A., Inc. v. Natural Res. Def. Council, Inc., 467 U.S. 837 (1984) (holding, in part, that executive branch regulations should be granted substantial deference when not contrary to the statutory scheme).

189. Yerdon v. Henry, 91 F.3d 370 (2d Cir. 1996) (analyzing the weight that should be given to EEOC guidelines and interpretations of Title VII).

190. Id. at 376 (citations omitted).

191. Id. (quoting Gen. Elec. Co. v. Gilbert, 429 U.S. 125, 142 (1976)); see also EEOC v. Arabian Am. Oil Co., 499 U.S. 244, 287 (1991) (applying the Gilbert standard and rejecting the EEOC's interpretation that Title VII applies extraterritorially because, in part, the interpretation contradicted the statute's plain language).

192. 728 F.2d 607 (3d Cir. 1984); see supra note 121 for discussion of Cleary.

193. Cleary, 728 F.2d at 610 n.6.

194. Id. 
protections of United States Law when employing individuals in the United States." 195 This conclusion completely lacks any analysis. The guidelines acknowledge the 1984 amendment to $\S$ 4(h), which specifies " $\mathrm{t}] \mathrm{he}$ prohibitions of this section shall not apply where the employer is a foreign person not controlled by an American employer," ${ }^{196}$ but they address the apparent plain language which suggests that the statute does not extend to any foreign firm unless that firm is controlled by an American company. While it is generally true that compliance with domestic laws merely constitutes a cost of conducting business within the United States, Congress's selection of this specific language certainly must be provided greater weight than an unsubstantiated conclusion by a self interested bureaucracy seeking to expand its reach.

"[T] he doctrine of expressio unis est exclusio alterius instructs that where a law expressly describes a particular situation to which it shall apply, what was omitted or excluded was intended to be omitted or excluded." ${ }^{197}$ As the Supreme Court recognized, "[t]he expressed purpose" of the 1984 ADEA amendments "was to "make provisions of the Act apply to citizens of the United States employed in foreign countries by U.S. corporations or their subsidiaries." "198 Even the EEOC acknowledges that "Congress amended the ADEA because it wanted to ensure that the citizens of the United States who are employed overseas by American Firms or their subsidiaries enjoy similar protections as citizens and aliens employed in the United States."199 Clearly an amendment which was enacted to address a specific issue and drafted in specific language should not be subject to expansion through the interpretation of a mere governmental agency and in contravention of the canons of statutory interpretation.

195. EEOC Policy Guidance,-915.039, Empl. Prac. Guide (CCH) If 5183 (Mar. 3, 1989) [hereinafter EEOC Policy Guidance].

196. Id. (citing 29 U.S.C. $\$ 623(\mathrm{~h})(2)(2000)$ ).

197. Reyes-Gaona v. N.C. Growers Ass'n, Inc., 250 F.3d 861, 865 (4th Cir. 2001) (rejecting the EEOC's contention that the 1984 Amendment provided ADEA coverage for foreign nationals who apply in foreign countries for jobs in the United States).

198. EEOC v. Arabian Am. Oil, Co., 499 U.S. 244, 259 (1991) (quoting S. ReP. No. 98-467 reprinted in 1984 U.S.C.C.A.N. 2974, 2975).

199. EEOC Policy Guidance, supra note 195. 
E. The Second Circuit's Decision: Fixing a "Black Hole" or Falling Down the "Rabbit Hole"?

Historically, Congress has been quick to disagree with judicial interpretations of the ADEA and Title VII, responding promptly with statutory amendments whenever it thought the judiciary misread its intentions. Although Congress has viewed its amendments as an effort "to restore the original congressional intent." 200 courts have refused to apply these "clarifications" retroactively, ${ }^{201}$ and instead have regarded them as expanding the scope of the statute's protections. ${ }^{202}$ Regardless of whether the amendments enlarge the scope of the ADEA or simply clarify and restate its existing scope, the histories of the 1984 and 1990 ADEA amendments, as well as the 1991 amendment to Title VII, show a congressional response to specific judicial holdings it deemed distasteful.

As discussed in section IIIA, the 1984 passage of the Older Americans Protection $\mathrm{Act}^{203}$ was a direct response to the Third Circuit's holding in Cleary that that the ADEA did not confer protections for American employees working overseas for American companies. ${ }^{204}$ Similarly, after the Supreme Court held that Title VII did not operate extraterritorially to protect U.S. citizens working abroad for American employers in Equal Employment Opportunity Commission v. Arabian American Oil Co. ${ }^{205}$ "Congress almost immediately responded to the Supreme Court's decision" ${ }^{206}$ by amending both Title VII and the $\mathrm{ADA}^{207}$ with language similar to the extraterritorial provisions of the ADEA. ${ }^{208}$

This history of legislative activism demonstrates that Congress is anxious to prevent American employees from falling into a "black hole" of non-

200. Older Workers Benefit Protection Act, Pub. L. No. 101-433, § 101, 104 Stat. 978 (1990) (codified in 29 U.S.C. $\S \S 621-626(2000)$ ).

201. See Wolf v. J.I. Case Co., 617 F. Supp. 858, 865 (E.D. Wis. 1985).

202. See id.

203. Older Workers Benefit Protection Act, §§ 101-105, 104 Stat. 978-983 (1990). Grassley).

204. Hearings: Age Discrimination and Overseas Americans, supra note 58, at 2 (statement of Sen.

205. EEOC v. Arabian Am. Oil Co., 499 U.S. 244, 258 (1991).

206. Melody Kubo, Extraterritorial Application of the Americans with Disabilities Act, 2 AsianPAC. L. \& POL'Y J. 259, 274 (2001).

207. Protection of Extraterritorial Employment Amendments, Civil Rights Act of 1991, Pub. L. No.

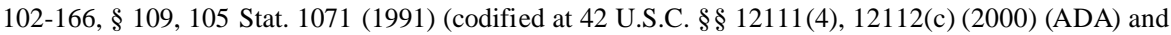
42 U.S.C. $\$ 2000 \mathrm{e}-1$ (c) (2000) (Title VII)).

208. Kubo, supra note 206, at 274. 
coverage and will act whenever it becomes necessary to clarify its true intent. This process is how the framers intended the divided branches of our Constitutional Republic to operate, and Congress's reticence in this instance does not justify the judiciary's legislation-making actions, as seen in Morelli.

The unstated motive underlying results-oriented decisions like Morelli appear to be the inclusion of putative employment discrimination victims within the protections of the various federal employment discrimination statutes - that is, preventing them from falling into the "black hole" of noncoverage. But the result is more akin to Alice's journey down the rabbit hole with a "Queen of Hearts" judiciary, rather than the politically accountable legislative process.

In its zeal to cast a safety net over this perceived deficiency of the ADEA, the Morelli court ignored the fact that one of the causes of action asserted by Ms. Morelli was a claim that Cedel violated the New York Human Rights Act. ${ }^{209}$ Most employing entities in the United States will, to a certain degree, find themselves subject to one or more of the various state or local employment discrimination statutes and ordinances. Calls for protecting putative victims of invidious employment discrimination employed by small domestic outposts of foreign employers do not go unheeded in the absence of ADEA coverage; all but the smallest of employing entities are covered by state statutes and local ordinances oftentimes paralleling the protections of their federal counterparts.

Rather than allow the genius of our federal system to operate as intended, courts, such as the Morelli court, ignore the plain text of the applicable statute and contort well-reasoned principles of statutory construction to prevent a result perceived by it as distasteful. In doing so, such courts usurp the role of Congress and create more problems than they solve-all the reason why such decisions are best left to Congress.

\section{Conclusion}

The Second Circuit's well-intentioned, albeit flawed, decision in Morelli poses broad implications for the global enforcement of American employment discrimination laws. Indeed, every significant shift in the application of the ADA, the ADEA, or Title VII potentially herald a change in the collective

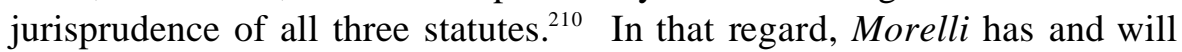

209. Joint Appendix, supra note 88 , at 29A, 36A.

210. This is a safe assumption, given the similarities between the three statutes. See, e.g., Robinson 
continue to serve as a springboard for the continued internationalization of American employment discrimination statutes. ${ }^{211}$ As a direct consequence, the overseas operations of foreign enterprises may become subjected to the investigative reach of the EEOC, and furthermore, these foreign enterprises are likely to be reluctant to invest in America and to employ our workers here at home-partly because the Second Circuit supplanted its will for that of Congress.

Morelli's internationalization of the ADEA not only subjects to possible liability a larger subset of employing entities than Congress truly intended, but this decision also provides the EEOC with a platform to extend its investigative tentacles around a larger subset of small businesses otherwise too small to be considered "employers" but for their foreign-controlled parent enterprises and the foreign workers employed on foreign soil. It is reasonable to presume, for instance, that Morelli may actually allow the EEOC's New York District Office to issue administrative subpoenas to executives of a European or Asian entity that owns or controls a small domestic subsidiary and that a federal judge in the Southern District of New York will enforce them. Suddenly, the EEOC may become the world's "equal employment opportunity" enforcer, regardless of whether or not the world-or Congress-wants it to be.

The EEOC, never in need of a reason to extend itself, will likely exploit decisions like Morelli to further advance its self-expanding mission on to the global stage despite the dearth of statutory authority to do so. ${ }^{212}$ With an

v. Overseas Military Sales Corp., 21 F.3d 502, 507 (2d Cir. 1994) ("It is well-established that ADEA claims are analyzed in the same manner as are claims under Title VII."); Marsili v. Arlington Heights Fire Dep't, 990 F. Supp. 578, 581 n.2 (N.D. Ill. 1998) ("The ADA, the ADEA, and Title VII use the same definition of 'employer."'); see also Moses v. Falstaff Brewing Corp., 525 F.2d 92, 94 (8th Cir. 1975) ("The similarity between Title VII of the Civil Rights Act and the Age Discrimination Act should also be recognized.") (citations omitted).

211. See Kang v. U. Lim Am., Inc., 296 F.3d 810 (9th Cir. 2003). In this recent case, the Ninth Circuit Court of Appeals relied upon Morelli v. Cedel to hold that the overseas workers employed by the foreign subsidiary of a small American company could be counted to reach the statutory minimum for Title VII. Id. at 816. Kang presents the paradigmatic case for the risks inherent in liberal interpretations of the anti-discrimination statutes. Rather than finding authority solely in the text of Title VII, the court in Kang relied upon the Second Circuit's decision in Morelli to hold that Title VII should be expanded to count overseas workers. Id. (discussing the Second Circuit's holding that overseas workers should be counted although not covered by the ADEA, the Ninth Circuit stated: "The Morelli court so concluded due, in part, to the policies behind limiting Title VII coverage ...."). Of course, in Morelli, the Second Circuit, without express authority in the language of the ADEA, relied upon the language and amendments of Title VII to hold that the ADEA has a similar overseas coverage as Title VII. See Morelli v. Cedel, 141 F.3d 39, 42-45 (2d Cir. 1998).

212. While the EEOC was created by the Civil Rights Act of 1964, Pub. L. No. 88-352, § 704, 78 
inherent need to validate its own existence, ${ }^{213}$ the EEOC has justified budget
requests-and its own existence-by touting its enforcement efforts, ${ }^{214}$ i.e.,
through its litigation statistics ${ }^{215}$ and the press release "bully pulpit." ${ }^{216}$ These

Stat. 258 (1964), the Commission was not originally empowered to enforce the law. Rather, the EEOC was limited to merely investigating claims of discrimination and seeking conciliation between the parties. Id. $\S 706$. It was not until 1972 and the Equal Employment Opportunity Act of 1972, Pub. L. No. 92-261, $\S 4(a), 86$ Stat. 104 (1972) (codified at 42 U.S.C. $\$ 2000 \mathrm{e}-4$ (2000)), that the EEOC was granted the authority to enforce the anti-discrimination laws which had been passed in the previous decade. During this period in the EEOC's history, between the grants of investigatory power and enforcement power, it was often described as a "toothless tiger" by civil rights groups. EEOC, The Story of the United States Equal Employment Opportunity Commission: Ensuring the PRomise of OpPortunity for 35 YeARs 5 (2000) [hereinafter EEOC: ENSURING THE Promise].

213. Trumpeting its self-proclaimed achievements through such matters as headline-grabbing settlement amounts, the EEOC leaves the distinct impression that success can only be measured by cases won and settlements obtained-the exact opposite of how rational people typically assess the successful implementation of a remedial measure - that is, by determining whether the remedial measure has truly caused a decrease in the frequency of the problem the remedial measure was designed to remediate-invidious discrimination here. Yet the EEOC's self-promoting scorecard seems to suggest that such invidious discrimination has gotten worse, not better, since 1964, despite a much more inclusive and diverse American workforce today than in the infancy of the civil rights movement.

214. This type of inherent conflict is not new in the arena of federal law enforcement. The late 1980s and 1990s witnessed a massive campaign to overhaul the Internal Revenue Service and curb the abuses in an agency empowered with concurrent authority to both investigate and prosecute the tax laws. See Steven Komarow, IRS Announces Punishments, Reprimands for Unruly Agents, USA TodAY, Sept. 15, 1998 at 5A (reporting IRS reprimanding dozens of employees and top managers to end "overzealous hounding of taxpayers"); William E. Gibson, Passage of Bill to Reform IRS Sets Stagefor WiderTax; Debate, Buffalo NEWS (New York), July 10, 1998, at 5A (reporting overwhelming support for reform of IRS due to taxpayer complaints); R. A. Zaldivar, IRS Chief: Changes Will Take Time, Phila. Inquirer, May 2, 1998, at A2 (noting that even the head of the IRS was disturbed by the testimony of abuses); Albert B. Crenshaw, IRS Oversight Plan Draws White House Fire, WASH. Post, Sept. 30, 1997, at A9 (discussing the debate over how to reform the IRS). As early as 1988, a Taxpayer Bill of Rights prohibited the IRS from instituting production goals or quotas on its agents. Omnibus Taxpayer Bill of Rights, Pub. L. No. 100-647, §6231, 102 Stat. 3730, 3734 (1988). Nearly ten years later, oversight of the agency continued as Congress mandated that the IRS annually submit a report detailing misconduct by agents during the preceding year. Taxpayer Bill of Rights II, Pub. L. No. 104-168, § 1211, 110 Stat. 1452 (1996).

That is not to suggest that the EEOC's zealousness rises to the level of the IRS agents who terrorized tax-law transgressors. See Robert Dodge, Commissioner Apologizes for Abuses at IRS; He Vows Immediate Reforms, Dallas Morning News, Sept. 26, 1997, at 1A (reporting of a Senate hearing in which IRS employees told of agents "tampering with jurors and witnesses, fabricating evidence and browsing through agency records to learn secrets about former husbands, potential boyfriends and enemies"). The EEOC's targets, discriminating businesses, are of course inherently less frail than the individual taxpayer, but analogies are far from unreasonable.

215. In August 2002, the EEOC issued a press release announcing the completion of an "extensive five-year litigation study" reporting that nearly $91 \%$ of all federal employment discrimination lawsuits asserted by the EEOC are resolved in its favor-either through Consent Decrees, settlement agreements or court orders. Press Release, Equal Employment Opportunities Commission, EEOC Issues Comprehensive Litigation Report (Aug. 13, 2002) (reporting success rate of 90.72\%), available at http://www.eeoc. gov/press/8-13-02.html (last visited Jan. 17, 2004) [hereinafter EEOC Litigation Report]. At trial and on 
measures have not gone unrewarded as the EEOC received over \$70 million in budget increases from 1997-2002. ${ }^{217}$ With this nearly $30 \%$ increase over a five-year period, the EEOC obtained a budget totaling over $\$ 310$ million in 2002. ${ }^{218}$ The internationalization of American employment discrimination laws will likely be too tempting for the EEOC to pass up. If the EEOC does indeed use Morelli to investigate foreign owned enterprises on foreign soil, it will likely ruffle international feathers at a time when anti-U.S. sentiment appears to be at an all-time high. The legitimacy of the EEOC's potential jurisdictional reach into these murky international waters pushes, if not exceeds, the bounds of its legitimate authority as currently established by Congress.

Moreover, Morelli's internationalization of American employment discrimination statutes does not bode well for the U.S. economy. Wary of being scrutinized by the American regulatory community and of being exposed to legal liability, foreign business enterprises are dissuaded from investing in the United States in a way that would actually employ more Americans. For instance, remedies under the various employment discrimination statutes include injunctive relief, back pay, front pay,

appeal, the EEOC's success rates are $60.24 \%$ and $80 \%$ respectively. Id. These numbers dwarf the private bar's success rate of only $26.8 \%$ at trial and a meager $16 \%$ on appeal. Id.

Remarkable as these numbers are, they are even more so when one considers that the EEOC has achieved these results while increasing the number of suits they have brought. In its 2002 annual release, the EEOC reported that between 1997 and 2002, its active litigation cases rose by over 87\%. See U.S. EeOC Office of General Counsel, Annual Report FY 2002, Pt. II.A. (2002), available at http://www.eeoc.gov/litigation/02annrpt.html(last visited Feb. 4, 2004). In 2002 alone, the EEOC's Office of General Counsel, the litigation arm of the EEOC, recovered over \$26.6 million for persons who filed federal discrimination claims. EEOC Litigation Report, supra. As Cari M. Dominguez, Chair of the EEOC, announced, the EEOC "will not hesitate to utilize litigation when necessary and appropriate." Id. Unanswered is the question of how the EEOC has man aged to achieve these victories during a period where critics suggest that the EEOC has been avoiding the largest defendants and the most political cases. Reed Abelson, Anti-Bias Agency is Short of Will and Cash, N.Y. TimEs, July 1, 2001, at 3-1 ("Although it does manage to process the tens of thousands of complaints it receives each year, the agency seems passive .... Its enforcement efforts often seem haphazard and uncoordinated, critics say, and it is noticeably absent in many lawsuits accusing the nation's most powerful companies ...."). Prosecutorial discretion certainly is one major factor, but to leave the matter at that minimizes the agency's slow but inexorable mission creep as an additional explanation.

216. See, e.g., EEOC Litigation Report, supra note 215 (describing results of EEOC litigation study). Further leaving the impression that dollars equals victories as the EEOC's own press releases posted on its website where, between October 2002 and October 2003, the EEOC posted thirty-seven press releases with titles containing settlement amounts or judgment awards ranging from $\$ 30,000$ to $\$ 47$ million. U.S. EEOC, EEOC Press Releases, available at http://www.eeoc.gov/press/index.html (last visited Feb. 10, 2004).

217. EEOC Office of Research, Information And Planning, Budget And Staffing (2002) (on file with authors).

218. $I d$. 
compensatory damages and punitive damages; and post-Morelli, the number of employees employed overseas by a foreign parent enterprise can affect the amount of liability to which such businesses, both foreign and domestic, are exposed. ${ }^{219}$

Concern for such uncertain legal exposure unquestionably impacts a foreign firm's willingness to invest in U.S. enterprises in a manner that would result in domestic job creation. Between 1997 and 2000, direct foreign investment in the United States increased from $\$ 70$ billion to $\$ 320$ billion. ${ }^{220}$ That rapid increase in investment dollars was, however, almost exclusively a result of foreign acquisition of U.S. businesses, as opposed to establishment of new businesses in the United States. ${ }^{221}$ According to Bureau of Economic Analysis (BEA) figures, while the foreign acquisition of U.S. businesses increased from $\$ 60$ billion to $\$ 316$ billion over the four year period from 1997 to 2000 , foreign investment to establish new domestic businesses actually decreased from nearly $\$ 9$ billion to $\$ 4.3$ billion. ${ }^{222}$ While the actual cause of this drop may never be known, the decrease does coincide with the Second Circuit's ruling in Morelli. Accordingly, Morelli could very likely have a deleterious effect on foreign investment in the American economy and may actually preclude the creation of new employment opportunities for Americans of every race, sex, age, etc.- that is, equal unemployment opportunities.

Given the constitutional, economic, and geopolitical implications involved, the decision to internationalize American employment discrimination statutes is certainly one better left to Congress.

219. See Greenbaum v. Svenska Handelsbanken, 26 F. Supp. 2d 649 (S.D.N.Y. 1998) (holding that after Morelli v. Cedel, the foreign employees of the defendant should be counted to determine the punitive damages cap underTitle VII). The Greenbaum court subsequently found that the previous punitive damage award of $\$ 50,000$, which had been based on number of employees the defendant had in the United States, should be increased to $\$ 300,000$ reflecting the total number of employees defendant had world-wide. Id. at 655 .

220. Ned G. Howenstine, Foreign Direct Investment in the United States: New Investment in 2000, SuRveY of CURRENT Business, June 2001, at 27, available at http://www.bea.doc.gov/bea/ARTICLES/ 2001/06June/060 1newi.pdf (last visited Feb. 10, 2004).

221. Id.

222. Id. 